\title{
Modern Devletin Açmazı: Dindar Topluma Seküler Sosyal Yapı 'Türkiye Örneği'
}

\author{
Fatih BAŞ
}

Atıf/Cite as: Baş, Fatih. “Modern Devletin Açmazı: Dindar Topluma Seküler Sosyal Yapı 'Türkiye Örneği' ". Recep Tayyip Erdoğan Üniversitesi İlahiyat Fakültesi Dergisi 20 (2021), 407-425.

\begin{abstract}
Öz: Bu makalede; modern siyasi, hukuki, kültürel araçlarla donatılan devlet aygıtının, toplumların dindarlığı karşısında yaşadığı ikilemler din ve sekülerleşme dinamikleri çerçevesinde Türkiye örneği üzerinden analiz edilmektedir. Sosyal ve siyasal yapının seküler sistemle tanzim edilmesine karşın, toplumun baskın dini ve manevi yönünün olması devlet aygıtının sosyal ve siyasal kontrol gücünü etkilemektedir. Devlet ve toplumun bütünlük arz etmediği bir yapıda özgürlükleri gözeterek kamu düzenini sağlamak, dini farklılıkları tolere etmek ve eşit vatandaş temelinde bir araya gelebilmek zorlaşmaktadır. Böylece siyasal, sosyolojik ve kültürel temelde bir devlet-millet birlikteliği sağlanamamaktadır. Bu doğrultuda makalede öncelikle kısa bir literatür taraması yapılmaktadır. Akabinde din, devlet, sekülerleşme üzerine kavramsal bir çerçeve çizilmekte ve sosyal yapının seküler boyutu ele alınmaktadır. Türk toplumunda bir sabite olarak dinin yeri ve modern dönemde dinin konumlanma sorunu incelenmektedir. Nihai olarak Türkiye'de sosyal yapının mı toplumun mu seküler olduğu tartışılarak makale tamamlanmaktadır. Makalede sosyal yapının sekülerliği ile toplum arasındaki ilişki merkeze alınmaktadır. Klasik yaklaşımlarda dindar toplumun sekülerleşmesi esas alınarak değerlendirmeler yapılırken, bu çalışmada sosyal yapıdaki sekülerleşmenin dindarlar üzerinde tezahürleri analiz edilmektedir. $\mathrm{Bu}$ perspektif çalışmaya özgün bir yön katmakta ve yeni açılımlar sunmaktadır.
\end{abstract}

Anahtar Kelimeler: Din Sosyolojisi, Türkiye, Sekülerleşme, Din, Toplum

* Arş. Gör., Aksaray Üniversitesi, Aksaray, Türkiye, fatihbas_002@hotmail.com, ORCID: www.orcid.org/0000-0002-3159-6770 


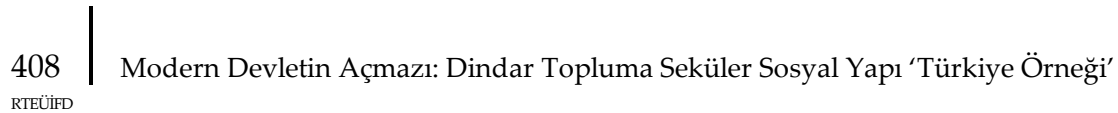

\title{
The Dilemma of the Modern State: Secular Social Structure to a Religiosity Society 'The Case of Turkey'
}

\begin{abstract}
In this article, the dilemmas faced by the state apparatus, was equipped with modern political, legal and cultural tools, in the face of religiosity of societies are analyzed through the case of Turkey within the framework of religion and secularization dynamics. Although the social and political structure is regulated by the secular system, the dominant religious and spiritual aspect of the society affects the social and political control strength of the state apparatus. In a structure where state and society do not have integrity, it becomes difficult to ensure public order by considering freedoms, to tolerate religious discrepancies, and to come together based on equal citizens. In this direction, primarily, it is done a brief literature review. Then, a conceptual framework is drawn over religion, state and secularization and the secular dimension of social structure is discussed. The place of religion as a constant in Turkish society and the positioning problem of religion in the modern period are examined. Finally, the article concludes by discussing whether the social structure or the society is secular in Turkey. The article focuses on the relationship between the secularity of the social structure and the society. While considerations are made on the basis of the secularization of religious society in classical approaches, in this article, the appearances of secularization in the social structure on religious people are analyzed. This perspective adds an original aspect to the study and submits new insights.
\end{abstract}

Keywords: Sociology of Religion, Turkey, Secularization, Religion, Society

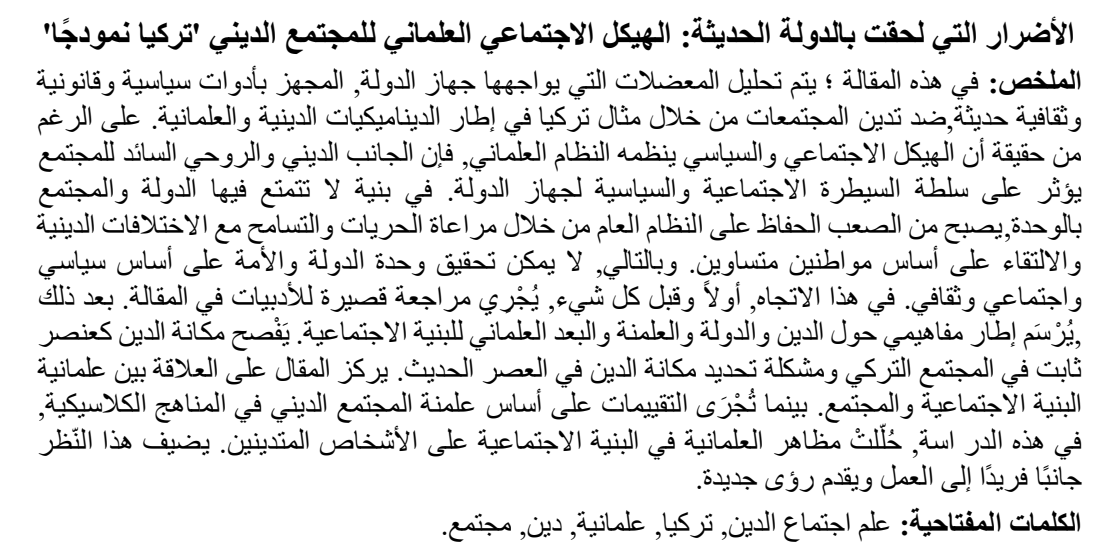

\section{GíRiş}

Yirmi ve yirmi birinci yüzyılın en çok üzerinde durulan konularından birisi de şüphesiz modernite sürecinin bir sonucu olarak ortaya çıkan sekülerleşmedir. Rönesans ve reform hareketleri ile bilhassa Avrupa'da sorgulanmaya başlanan kilise tahakkümü, süreç içerisinde bu sorgulamaların neticesinde toplum nezdinde gücünü ve otoritesini kaybetmeye başlamıştır. Bu kayıp tanrı merkezli dünya anlayışından insan merkezli dünya anlayışına doğru bir değişimi beraberinde getirmiştir. Aslında 
bu değişimin ilk sinyalleri hümanizm ile başlamış, insanı ve onun biricikliğini merkeze alma hümanist felsefenin temel amacı olmuştur. ${ }^{1}$ Modernitenin öngördüğü yeni süreçte akıl, bilim ve teknik ön planda yer almış ve toplumun tabiata dair araştırdığı her sorunun ve her bilinmezliğin cevabı rasyonalite ve bilim ekseninde verilmiştir. ${ }^{2}$ Modernitenin kendini oturttuğu temele bakıldığında devlet ve toplum tahayyülünde din kurumunun yerinin olmadığı anlaşılmaktadır. Oysa ki tarihsel hafızada din kurumu sosyal yapıda fonksiyonel bir göreve sahiptir.

Tarihsel ve sosyolojik perspektiften baktığımızda din ve inanç insanoğluyla birlikte hep var olagelmiştir. İster beşerî ister semavi olsun din, insanların yaşamlarını belirlemede, davranışlarını şekillendirmede ve toplumları idare etme noktasında sürekli bir etkiye sahip olmuştur. İnsanoğlunun varoluşuna dair anlamlandırmak istediği ve içinden çıkamadığı pek çok noktaya din 1şık tutmaktadır. ${ }^{3}$ Din, yaşam gayesini anlamlı hale getirdiği için insanlar adına vazgeçilmez bir kurum olmaktadır. Modernitenin amaçları doğrultusunda oluşan sekülerleşme ise dinin devlet ve toplum üzerindeki rolünü baskılamak için araçsallaştırılmış dünyevi yapısal bir düzene işaret etmektedir. Diğer bir ifadeyle Tanrı'nın sosyal yapıyı şekillendirme iradesinin yerine birey ve rasyonel aklın sosyal yapıyı şekillendirme iradesi ortaya çıkmaktadır. ${ }^{4}$ Sosyal yapının seküler unsurlarla donatıldığı bir sistemde bireyin dindarlığını yaşayabileceği yer özel alanla sınırlandırılmaktadır. Birey, özel alanın dışında okul, üniversite veya diğer devlet kurumları gibi kamusal hayata dahil olduğu anda seküler sistemin dayatmaları ile yüzleşmekte, dinin taleplerini kamusalın içinde serbestçe yerine getirememektedir. Bu durum bireyin devlet ile vatandaşlı̆̆ın ötesinde sosyal ve kültürel aidiyet kurmasını zorlaştırmaktadır.

Sekülerleşme olgusunun toplumların bünyesine yerleştiğini düşünen, 20. yüzyılın sekülerleşmenin yüzyılı olacağını ifade eden Bryan Wilson ve Steve Bruce dinin geçmişe oranla sosyal yapıyı düzenleme gücünün büyük ölçüde azaldığını iddia etmektedir. ${ }^{5}$ Buna karşın Rodney Stark ve Peter Berger gibi sosyologlar dinin farklı boyutlarıyla sosyal yapıda yer aldığını ve aslında dinin dizayn edici rolünün devam ettiğini belirtmektedirler. ${ }^{6}$ Karl Dobbelaere ve Jose Casanova ise hem sekülerleşme hem de dinin sosyal yapıyı birlikte şekillendirebilme potansiyeli taşıdığını düşünmektedirler. Onlara göre modernitenin sunduğu yeni yaşam biçimini din,

1 Şükrü Akkaya, “Hümanizm' in Çıkışı ve Yayılışı”, Ankara Üniversitesi Dil ve Tarih-Coğrafya Fakültesi Dergisi 5/2 (1947), 208-209.

2 Ali Köse, 21. Yüzyılda Dinin Geleceği: Kutsalın Dönüşü (İstanbul: Timaş Yayınları, 2014), 12.

3 Celil Abuzar, "Din-Toplum Etkileşimi ve Eğitim”, Harran Eğitim Dergisi 2/2 (2017), 51.

4 Charles Taylor, Seküler Çă̆ (İstanbul: Türkiye İş Bankası Yayınları, 2014), 32-35.

5 Bryan Wilson, Seküler Toplumlarda Din, çev. Ömer Faruk Darende (Ankara: Pegem Yayınları, 2017), 45-65.

6 Rodney Stark, “Secularization”, Journal of Sociology of Religion 60/3 (1994), 237-241. 


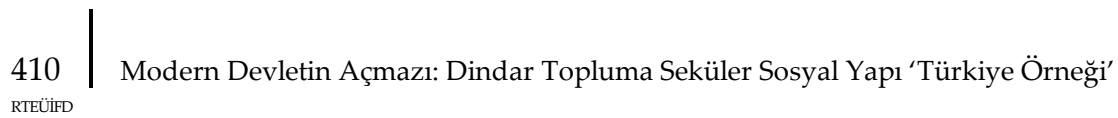

kendi dinamikleri doğrultusunda içselleştirip, kendini modern salvolara karşı hazırlıklı hale getirmektedir. Casanova, Avrupa ve Amerikan sekülerliğini mukayese ederek, farklı boyutlarıyla sekülerliği ve dindarlığı ortaya koymaktadır. ${ }^{7}$ Bir diğer isim David Martin de sekülerleşmenin modernitenin bir parçası olduğunu ve dinin sosyal yapıdaki düzenleyici fonksiyonunu kısmen azalttığını ancak dinin modern versiyonlarla yeniden kendini topluma sunarak seküler olgulara karşı gücünü koruduğunu savunmaktadır. ${ }^{8}$

Modern devletin kurgulanış biçiminin toplumun dini, sosyal, kültürel kodlarıyla uyuşup uyuşmadığı meselesi tartışılması gereken bir husustur. Çalışmanın merkezini Türkiye'de siyasal ve hukuki sistemin tasarımı ile toplumun buna gösterdiği reaksiyonun bileşkesi oluşturmaktadır. Modernitenin Türkiye'de dizayn ettiği sosyal yapıyı analiz etme, günümüzde din ve sekülerleşme tartışmalarını anlama noktasına da kaynak teşkil edecektir. Çalışmanın evrenini Cumhuriyetin ilanından sonra gerçekleştirilen modernleşme çalışmalarının günümüze dek olan yansımaları oluşturmaktadır. Zamansal çizelgede çalışma 1923-2021 yılları arasını analiz etmektedir. Cumhuriyetle birlikte modernleşme adı altında gerçekleştirilen reformların sosyal yapıda meydana getirdiği değişim ile bunun topluma nasıl sirayet ettiği incelenmektedir. Çalışmada sosyal yapının seküler dizaynı ile dinin modern devletteki konumu birey ve topluma yansımaları bağlamında çeşitli alanlar üzerinden ele alınmaktadır. Böylece genel kanaatin aksine toplumun sekülerliğinden sosyal yapıya bakmak yerine, yapının sekülerliğinden topluma bakılmaktadır. Bu durum çalışmaya spesifik bir bakış açısı kazandırmaktadır. Uzun bir tarihsel süreci kapsadığı için çalışmanın en önemli sınırlılığını geçmişi yaşayarak ve gözlemleyerek değil ancak yazılı kaynaklardan mütalaa edişimiz oluşturmaktadır. Çalışma yakın geçmiş ile bugün arasında karma bir sürece odaklanmaktadır. Ayrıca çalışma yöntem bilimsel açıdan hermenötik disiplini çerçevesinde ele alınmaktadır. Hermenötik; her türlü metinsel, görsel, sözsel bilgi ve belgelerin belirlenen konu etrafında metodolojik olarak yorumlanması anlamına gelmektedir. ${ }^{9}$

\section{Kavramsal Çerçeve}

Modernleşme sürecinin tam olarak ne zaman başladığı sosyolojik metinlerde net olarak yer almamaktadır. Buna karşın modernleşme sürecini başlatan birtakım olgulardan bahsedilmekte ve bunlar; teknolojik-bilimsel bilginin artması, doğaüstü alana ilginin azalması, tarımsal faaliyetlerin ticari amaçlı yapılmaya başlanması, makineleşme-sanayileşme ve kırsaldan kente göç gibi sebepler olarak açıklanmaktadır. Modernleşmenin ana öğelerinden birisi geleneksel anlayışlardan

Jose Casanova, “The Secular and Secularisms", Journal of Social Research 76/4 (2009), 1055-1056.

8 David Martin, A General Theory of Secularization (Oxford: Blackwell Publishing, 1978), 14-16.

9 Seyit Coşkun, "Sosyal Bilimlerde Metodoloji Problemi", Dört Öge Dergisi 13 (Haziran 2018), 63. 
sıyrılıp, yeni ve ilerlemeci bir anlayışa sahip olmaktır. ${ }^{10}$ Bir diğer önemli öğesi ise geçmişte toplumun bütün katmanlarını yöneten ve yönlendiren dinin yerine, her bir alanın kendine özgü kuralları olması gerektiğini savunan ve bürokratik temellere dayanan Weberyan rasyonalitenin ortaya çıkmasıdır. ${ }^{11}$ Buna göre siyaset, hukuk, eğitim, toplum, kültür gibi her bir alan kendi kurallarını dinden bağımsız, rasyonel biçimde belirlemiştir.

Din ve devlet kavramları çok eski tarihlerden beri kullanılagelmekte iken sekülerleşme ve sosyal yapı kavramları onlara göre daha yakın tarihe ait bir kavramsallaştırma olarak durmaktadır. Ayrıca din içerisinde çeşitli beşerî ve semavi oluşumları barındırmakta, aynı şekilde devlet kavramı da yaklaşık beş-altı bin yıllık tarihi kayıtlar çerçevesinde kurulup, yıkılan birçok devleti ve devlet modellerini kapsamaktadır. Buna karşın sekülerleşme ve sosyal yapı kavramları daha çok sosyolojik tahlillerle ilintilidir. Sosyoloji disiplini modern döneme ait olduğu için bu kavramlar da modern dönemi simgelemektedir.

Din, tek başına inançtan ibaret değildir. Bunun yanında hukuki, sosyal ve ahlaki olarak da insanları beslemektedir. Ayrıca kimine göre din 'cemaatlerin bir ideolojisi' olarak da değerlendirilmektedir. ${ }^{12}$ Din sadece bireylerden meydana gelmemekte, aynı zamanda ortak aidiyeti paylaşan bireylerin oluşturduğu bir sosyal birliktelik olan cemaat olgusunu da şekillendirmektedir. Bu sebeple din ferdilikten sosyalliğe, maneviyattan dünyalığa doğru bir anlamı da ifade etmektedir. İnsan bir taraftan dinin getirilerini yerine getirmekle sorumlu iken, diğer taraftan da içerisinde bulunduğu toplumun kurallarına uymakla mükelleftir. ${ }^{13}$

Devlet, belirli bir toprak parçası üzerinde kurulan, hukuk çerçevesinde örgütlenen, askeri ve ekonomik yapılarını oluşturan ve bağımsız bir karakter arz eden yapı olarak tanımlanmaktadır. Engels'e göre ise devlet, ezilen sınıfı kontrol altında tutmak ve egemen sınıfın çıkarlarını muhafaza etmek için vardır. ${ }^{14}$ Devlet; topluma refah, hukuk ve güvenlik hizmetleri sunan siyasal bir organizasyondur. İçerisinde monarşi, oligarşi, demokrasi gibi farklı yönetim modellerini benimseyen devlet, insanın var oluşu ve bir arada yaşayışı kadar eski bir tarihe dayanmaktadır.

Sekülerleşme kavramı ilk olarak 17. yüzyılda kullanılmaya başlanmış ve 1648 yılında Avrupa devletleri arasında imzalanan Westfalya Barış Anlaşmasıyla birlikte literatüre girmiştir. Geçmişte kilise kontrolü altında bulunan toprakların laik siyasi

\footnotetext{
10 Anthony Giddens, Modernliğin Sonuçları, çev. Ersin Kuşdil (İstanbul: Ayrıntı Yayınları, 2016), 12-14.

11 Max Weber, Bürokrasi ve Otorite, çev. Bahadır Akın (Ankara: Adres Yayınları, 2017), 24.

12 Wilson, Seküler Toplumlarda Din, 82-86.

13 Ömer Faruk Harman, "Din ve Vicdan Hürriyeti", Türkiye Diyanet Vakfı İslam Ansiklopedisi (Ankara: TDV Yayınları, 1994), 9/340.

14 Frederic Engels, Ailenin, Özel Mülkiyetin ve Devletin Kökeni (Ankara: Alter Yayıncılık, 2013), 215-216.
} 


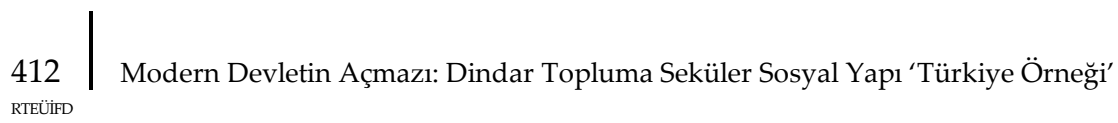

yönetimlerin otoritesine geçmesini tanımlamak için kullanılmıştır. Daha genel anlamıla bir toplumda din ve dinimsi yapıların bireysel ve toplumsal etki gücünün süreç içinde azalması olarak tanımlanmaktadır. Diğer bir ifadeyle doğaüstü alanla birey tarafından kurulan ilişkinin zayıflaması şeklinde ifade edilmektedir. ${ }^{15}$ Kavramı sosyoloji literatürüne kazandıran Weber'e göre, rasyonelleşme sürecinin bir parçası olarak dinin toplumsal rolünü kaybetmesi ve büyü bozumu süreci olarak kabul edilmektedir. ${ }^{16}$ Sekülerleşme kavramı 20. yüzyıldan itibaren sosyolojik bir bakış açısıyla yeniden yorumlanmış ve dini otoritenin yer, zaman ve kişiler üzerindeki toplumsal kontrolünü kaybedip, onun yerine fazlaca dünyevi amaçlara odaklanan bir süreci anlatmak için kullanılmaya başlanmıştır. ${ }^{17}$ Sekülerleşme olgusunun temel sorunsalı, toplumun işleyişinde dinin rolü ile ilişkili olmuştur. Sekülerleşme, bireysel ilişkileri ve kurumsal işleyişi belirleyen ana unsurun din değil, rasyonalite ve sistem olması gerektiği görüşünü savunmaktadır. ${ }^{18}$

Sosyal yapı, bir toplumun sahip olduğu fiziki çevrenin, siyasi ve kültürel yapının, kamu kurum ve kuruluşlarının üstlendiği rol, benimsediği norm ve edindiği statülerin bütünsel organizasyonu olarak tanımlanmaktadır. Sosyal yapı statik ve dinamik olmak üzere iki şekilde ele alınır ve statik yönü yapıyı, dinamik yönü ise toplumu temsil etmektedir. ${ }^{19}$ Sosyal yapıyı oluşturan bütün unsurlar belli kurallar manzumesi doğrultusunda hareket eder. Toplumsal ilişkiler, gruplar, demografik özellikler, yerleşim biçimleri birer sosyal yapı unsurlarıdır. ${ }^{20}$

\section{Türkiye'de Sosyal Yapının Seküler Dizaynı}

Türk toplumunun sosyolojik dağılımı kozmopolit bir yapıya sahiptir. Muhafazakâr popülasyonun ağırlıkta olduğu toplumsal yapıda seküler kesimin de azımsanmayacak derecede temsiliyeti vardır. Ayrıca toplumsal yapı içerisinde liberal ve milliyetçi tandanslı popülasyonda bulunmaktadır. ${ }^{21}$ Türkiye'de muhafazakâr/dindar kesimin ağırlıkta olduğu sosyolojik dağılım Osmanlı'dan beri devam etmektedir. Modern Türkiye'nin kuruluşuyla siyasal, kültürel ve hukuki sistem değişirken, toplumsal sistemdeki dağılımlar değişmemiştir. Türkiye' de sosyal yapıyı oluşturan ve belli kuralları yerleştiren birçok kurum bulunmaktadır. Sosyal yapı; siyasal, kültürel, hukuki, ekonomik açılardan şekillenme kapasitesine sahiptir.

\footnotetext{
15 Volkan Ertit, Sekülerleşme Teorisi (Ankara: Liberte Yayınları, 2019), 47.

16 Niyazi Akyüz - İhsan Çapçığlu, Din Sosyolojisi (Ankara: Grafiker Yayınları, 2012), 409.

17 Mehmet Ali Kirman - İhsan Çapçığlu, Sekülerleşme: Klasik ve Çă̆daş Yaklaşımlar (Ankara: Otto Yayınları, 2015), 10-12.

18 Mehmet Özay, Sekülerleşme ve Din (İstanbul: İbn Haldun Üniversitesi Yayınları, 2020), 122-124.

19 Mustafa Aydın, Güncel Kültürde Temel Kavramlar (İstanbul: Açlım Yayınları, 2011), 413-414.

20 Ünver Günay, Din Sosyolojisi (İstanbul: İnsan Yayınları, 2012), 25.

Bk. Hakan Yılmaz, Türkiye'de Muhafazakarlık, Aile, Din ve Batı, Yayımlanmamış Araştırma Raporu, Ocak 2006.
} 
$\mathrm{Bu}$ unsurlar sosyal ilişkilerde sosyal yapının tanzim edilmesinde önemli bir işleve sahiptir. Bundan ötürü sosyal yapının anlamlı hale gelebilmesi için kurumlar kadar kişiler de mühimdir. ${ }^{22}$ Sosyal yapının kurumlar, kanunlar ve kamusal alan aracılığıyla bireye ve topluma sunduğu kurallar toplumun davranış, düşünce ve yaşam pratiklerini etkilemektedir. Birey, kamusal alanda sosyal yapının ona dayattığı kuralların dışına çıkmak istese de toplumun bir parçası olduğu için bunu kabullenmek durumunda kalır. Sosyal yapı geleneksel dünyada din, kültür ve yerel unsurlarla harmanlanarak inşa edilmekte iken, modern dünyada bilim ve rasyonalitenin ürettiği seküler olgularla meydana getirilmektedir. Dolayısıyla sosyal yapının seküler kalıplarla tasarımı ile toplumun seküler hayat tarzına eğilimi aynı çerçevede değerlendirilmez. Yapının sekülerliği, düşünsel ve ideolojik bir bakış açısının topluma giydirilme biçimini ifade ederken, toplumun sekülerliği ise iradi ve istenç bir şekilde hayat tarzını dönüştürme anlayışını yansıtmaktadır. Sosyal yapı ile toplum ilişkisinin dönüşümü İslam toplumları ile Batı toplumları arasında farklı parametreler doğrultusunda gerçekleşmiştir.

Modernleşme tecrübesi Batı'da kültürel, entelektüel ve siyasal süreçlerin tedricen ürettiği bir sonuç iken, İslam dünyasında ve özelde Türkiye' de modernleşme Batı üstünlüğü anlayışının ve Batı'nın yayılmacı politikalarının 20. yüzyıldaki ideolojik aygıtı olmuştur. ${ }^{23}$ Modern Türkiye'nin kuruluşu ile hızlı bir reform süreci hayata geçirilmiştir. Siyasi alanda başlayan, yönetim sisteminin değişimini beraberinde dini, hukuki, kültürel, ekonomik alanlarda başlatılan değişimler izlemiştir. Halkın direkt olarak yönetime katıldığı ve kendisini yönetecek kişileri belirlediği demokratik düzen yeni kurulan devletin öncelikleri arasında olmuştur. Cumhuriyetin yanı sıra, bağımsız bir ülke olmak ve ulusunu öncelemek adına milliyetçilik, halkın taleplerine göre politika belirlemek adına halkçılık, sürekli reformist bir çizgi takip etmek adına inkılapçılık, din ve devlet işlerinin ayrı yürütülmesi adına laiklik, devletin yatırım ve istihdam üretmesi adına devletçilik ilkeleri benimsenmiştir. ${ }^{24} 1922$ yılında Saltanatın Kaldırılması ve akabinde 1923 yılında Cumhuriyetin ilan edilmesiyle birlikte modern Türk devletinde yeni bir dönem başlamıştır. 1924 yılında TBMM'de çıkarılan kanunla Hilafet makamı da kaldırılmıştır. Aynı tarihte kabul edilen Tevhid-i Tedrisat Kanunu ile tüm medreseler kapatılmış ve eğitim kurumları Millî Eğitim Bakanlığı bünyesinde toplanmıştır. Ayrıca Erkan-ı Harbiye Vekaleti kaldırılmış, yerine Genelkurmay Başkanlığı

22 Claude Levi-Strauss, "Sosyal Yapı", çev. Erdoğan Güçbilmez, Ankara Üniversitesi Siyasal Bilgiler Fakültesi Dergisi 20/2 (1965), 683.

23 Talip Küçükcan, “Modernleşme ve Sekülerleşme Kuramları Bağlamında Din, Toplumsal Değişme ve İslam Dünyası", İslam Araştırmaları Dergisi 13 (2005), 117.

24 Mark Landau, Atatürk ve Türkiye'nin Modernleşmesi, çev. Meral Alakuş (İstanbul: Sarmal Yayınevi, 1999). 


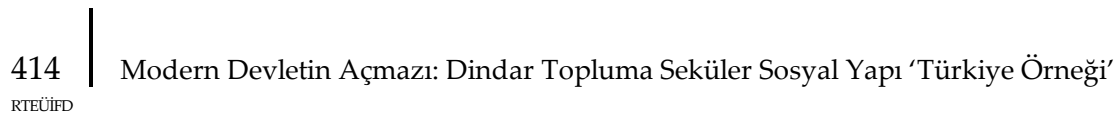

kurulmuştur. Şeriye ve Evkaf vekaletinin yerine de Diyanet İşleri Başkanlığı ile Vakıflar Genel Müdürlüğü ihdas edilmiştir. ${ }^{25}$

Moderniteyle sosyal yapının bütünüyle seküler unsurlarla donatılması ve toplumun seküler düzene entegre edilmesi hedeflenmiştir. Süreçle birlikte sekülerleşmenin bizatihi kendisi kutsal bir olgu olarak addedilmiş ve dinin yerine ikame edilmeye çalışılmıştır. ${ }^{26}$ Türkiye' de modernleştirme çalışmaları siyasal, askeri ve dini alanlardan sonra hukuki, sosyal ve kültürel alanlarla devam etmiştir. Bu doğrultuda Osmanlı'dan beri kullanılagelen Hicri takvim kaldırılmış ve 1925 yılında Miladi takvim kabul edilmiştir. Yine 1926 yılında Mecelle olarak bilinen modern Osmanlı hukuk sistemi lağvedilmiş, yerine çeşitli Avrupa ülkelerinden alınan ceza, aile, ticaret hukukları ile oluşturulan Türk Medeni hukuku yerleştirilmiştir. 1928 yılında TBMM'de kabul edilen yasayla yeni Latin alfabesi yürürlüğe girmiştir. Aynı yıl anayasadan 'devletin dini İslam'dır' ibaresi çıkarılmıştır. 1937 yılına ise kurucu lider Atatürk'ün altı ilkesi anayasaya girmiştir. ${ }^{27}$ Modernleşmenin hızlı bir şekilde sürdürüldüğü dönemde İslami kimliği baskın olan toplumsal gruplar mevcut sisteme karşı direnç göstermişlerdir. Laiklik, eşitlik, bireyselleşme kavramları üzerinde yoğunlaşılması, köklü dinsel ve cemaatsel temellere sahip Osmanlı bakiyesi toplumun bir kesimini önemli oranda rahatsız etmiştir. Batı yanlısı hukuki, kültürel, politik bir ajandanın takip edilmesi ve bu doğrultuda reformların gerçekleştirilmesi batılılaşmaya hazır bireyler ile İslami kimliği ağır basan gruplar arasında ciddi bir ayrışma yaratmıştır. ${ }^{28}$ Cumhuriyetin ilanıyla birlikte hayata geçirilen reformlar her ne kadar modernleştirici birer unsur olarak kabul edilse de bunların gerçekleştiriliş biçimi halkın görüş ve önerileri doğrultusunda aşağıdan yukarı katılımcı bir anlayışla yapılmamıştır. Belli bir azınlık grubun kendi aralarında aldıkları kararlar doğrultusunda uygulamaya konulan reformlar bu yönüyle beraber tepeden inmeci ve dayatmacı bir yapıya sahiptir. Toplumun modernleştirilmesi karşılıklı diyalektik bir ilişkiyle beraber ikna ve rıza yoluyla değil, baskıcı ve kabul ettirmeci bir anlayışla gerçekleştirilmiştir. ${ }^{29}$ Bundan ötürü Cumhuriyet reformları azınlık bir kesim tarafından benimsenirken, geniş bir toplumsal kesim tarafından geçmiş kültürel kodları, inancı ve değer yargıları ile bağdaşmayacağı gerekçesiyle eleştirilmiştir. Modern Türkiye, halkın bütünüyle ortak bir mutabakat neticesinde değil, halkın önemli bir kesiminin itirazlarına rağmen siyasi, hukuki, dini, kültürel, sosyal alanlarda modernleşme ve sekülerleşme deneyimini hayata geçirmiştir.

25 Andrew Mango, Atatürk: Modern Türkiye'nin Kurucusu, çev. Füsun Doruker (İstanbul: Remzi Kitabevi, 2004).

26 Mustafa Tekin, Kutsal Sekülarizm (İstanbul: Açılım Kitap, 2011), 41-42.

27 Şerif Mardin, Türkiye'de Din ve Siyaset (İstanbul: İletişim Yayınları, 2012), 97-98

28 Nilüfer Göle, Modern Mahrem (İstanbul: Metis Yayınları, 2011), 36.

29 Niyazi Berkes, Türkiye'de Çağdaşlaşma (İstanbul: Doğu-Batı Yayınları, 1988). 


\section{Türkiye'de Bir Sabite Olarak Din}

İnsanın özgür iradesine dayalı olarak kabul edilen din, dünyevi ve uhrevi amaçlar doğrultusunda bir yaşam tarzı önermektedir. Din, ontolojik boyutu ile aşkın varlıkla kurulan ilişkiye aracı olması nedeniyle bireyin dünyevi hayatta önemli bir boşluğunu doldurmaktadır. Varlığın amaçlı ve anlamlı hale getirilmesinde kritik bir rolü olan din kurumu bireye gündelik hayata dair genel davranış ve tutum pratikleri sunduğu için de anlamlıdır. Yaşadığımız dünyayı kutsal kozmos olarak nitelendiren Luckman'a göre din, semboller ve onun ihtiva ettiği anlamlar ile bütüncül olarak bir dünya görüşünü ifade eder. Bundan dolayı din, sembolik temsiller vasıtasıyla kutsal kozmosta yerini daima korumaktadır. ${ }^{30}$ Bireyin duygu dünyasına seslenişi ve içsel terapisine yardımcı olması sebebiyle de birey için bir sı̆̆ınma aracı vazifesi görmektedir. Birey ve toplum için din, en zor şartlarda dahi başvurulabilecek, ilahi dayanaklı bir kurtarıcı kurumdur. Dine yüklenen bu misyon bireyin koşulsuz şekilde dini referans kaynağı olarak görmesine olanak sağlamaktadır. Din, bir taraftan bireyin günlük hayatını kolaylaştıran rehber iken, öte yandan makro ve mikro ölçekli anlam arayışlarına ve varlığı sorgulamalarına cevap üretebilen metafizik bir olgudur.

Türk toplumunda din olgusu, modernleşme deneyimi ve siyasal süreçten bağımsız algılanabilecek bir durum değildir. Modern Türkiye'nin sınırları seküler unsurlar çerçevesinde çizilmiş, bunun uygulanabilmesi için de din olgusu mutlaka kontrol altında tutulmak istenmiştir. ${ }^{31}$ Din kurumu, Türk devletlerinin ve toplumunun tarihsel süreçte sürekli merkezinde yer almıştır. Bilhassa Selçuklu ve Osmanlı'nın devlet sistemi içerisinde kilit role sahip olan din, asırlar boyu Türk toplumunun siyasi, sosyal, ekonomik, kültürel birçok alanında belirleyici bir vazife üstlenmiştir. Osmanlı hükümdarlarının bir süre hilafet makamını temsil etmeleri de dinin toplumsal gücünü pekiştirmiştir.32 Geleneksel dönemde devletin işleyişi, kamusal düzen, ekonomik sistemin dizaynı, aile ve ticaret hukuku gibi birçok alan din kurumunun önerileri doğrultusunda tanzim edilmiştir. Türk toplumunun sahip olduğu güçlü kültür ve medeniyet birikiminin oluşumunda da din kurumunun önemli katkısı vardır. Türk toplumunda inanç ve maneviyatın baskın olması dini toplumsal ve kurumsal düzlemde sürekli bir ihtiyaç haline getirmektedir.

Türkiye' de modernleşme süreciyle her ne kadar köklü bir toplumsal değişim ve dönüşüm sağlanmak istense de toplumun din ile olan güçlü bağları devam etmiştir. Laiklik çerçevesinde gerçekleştirilen reformlar, dini kurumların lağvedilmesi ve

30 Thomas Luckman, Görünmeyen Din: Modern Toplumda Din Sorunu, çev. Ali Coşkun vd. (İstanbul: Rağbet Yayınları, 2016), 116.

31 Recep Şentürk vd., Türkiye'de Dindarlık (İstanbul: İletişim Yayınları, 2012), 97.

32 Cağfer Karadaş, "Selçukluların Din Politikası", Necmeddin Erbakan Üniversitesi İlahiyat Fakültesi Istem Dergisi 1/2 (2003), 108. 


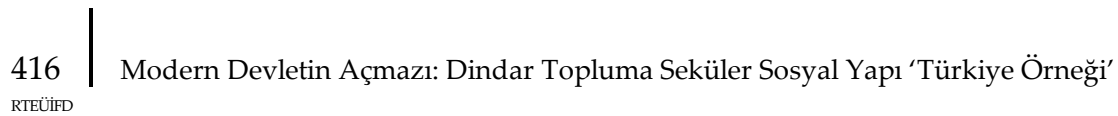

eğitim kurumlarının seküler sistemle kurulması seküler bir toplum inşa etme amacı taşısa da dinin toplumsal hafızada edindiği güçlü bağ ortadan kalkmamıştır. Toplumun büyük bir kısmı inançlı olduğunu, temel dini saiklere bağlı bulunduğunu dile getirmektedir. Türk toplumunun yaklaşık \%70-75'lik kısmının muhafazakâr/dindar eğilimde ${ }^{33}$ olduğu göz önüne alındığında dinin modernite karşısında bireysel olmasa da kurumsal ölçekli gücünü sürdürdüğünü göstermektedir. Toplumun dinin temel kaideleri -Allah, Peygamber, Kur'an gibi- ile barışık bir ilişki geliştirdiği anlaşılmaktadır. Buna karşın dini ritüel ve pratiklerin toplumda yeteri kadar yaşanmadığı araştırmalara yansımaktadır. Bu durum günümüzde dinin kurumsal boyutuyla bir sabite olarak toplumda yer edindiğini göstermektedir.

Modern Türkiye'nin inşa döneminde gerçekleştirilen devrimlere toplumun verdiği reaksiyonlar da din ile ilişkiyi anlama noktasında bizlere fikir verebilmektedir. Reformların azınlık bir kesimin elinden çıktığı kuruluş sürecinde ortaya çıkan toplumsal karşıtlıkların merkezinde dinin modern devlette konumlanma sorunu yatmaktadır. ${ }^{34}$ Dini birçok kurumun ortadan kaldırılması ve yeni yapıda kendi özel alanına çekilmesi, toplumsal reaksiyonlara sebebiyet vermiştir. Ayrıca Türkiye'de tüzel kimliğe sahip olmayan cemaat ve tarikat tarzı yapıların büyümesi ve bünyesinde çok sayıda müntesip barındırması da Türk toplumunda dinin ifade ettiği anlamı kavrama noktasında önemli bir aşamadır. Din kurumu Anadolu coğrafyasında asırlardır edindiği tecrübe ile toplumsal bir realite halini almaktadır. ${ }^{35} \mathrm{Bu}$ bağlamda dine göre çok daha yeni bir süreç olan modernitenin eski bir toplumsal sabite olan din ile nasıl ilişki kurduğu Türkiye modelinde ele alınmalıdır.

\section{Modern Devlette Dinin Konumlanma Sorunu}

Tarihsel olarak devlet kavramı, toplumların güvenlik, sağlık, eğitim gibi taleplerine cevap vermek için üretilmiş bir örgütlenme biçimidir. Belli bir zaman dilimi içerisinde hüküm süren, kuruluş ve yükseliş evreleri ile gerileme ve yıkılma evrelerine sahip bir mekanizmadır. ${ }^{36}$ Din ise toplumların inanç, maneviyat ve ahlak ihtiyacını karşılamaktadır. Ortaçağ Avrupa'sında dinin temsilcisi konumundaki kilise aynı zamanda toplumun siyasi, kültürel, bilimsel, hukuki bütün süreçlerinin planlayıcısı ve yürütücüsüdür. Kilise sosyal yapının en güçlü tasarımcısı konumundadır. Geçmişten günümüze insanlık tarihi dini devlet ile profan devlet olmak üzere iki model arasında sürekli bir git gel yaşamıştır. Dünyada bugün ağırlıklı

33 Yılmaz Esmer, Türkiye Değer Atlası (İstanbul: Bahçeşehir Üniversitesi Yayınları, 2012).

34 Erik Jan Zürcher, Modernleşen Türkiye'nin Tarihi, çev. Yasemin Saner (İstanbul: İletişim Yayınları, 2018), 205-206.

35 Mehmet Fuad Köprülü, Anadolu'da İslamiyet, haz. Hasan Aksakal (İstanbul: Alfa Yayınları, 2017).

36 İbn Haldun, Devlet, çev. Osman Arpaçukuru (İstanbul: İlke Yayıncılık, 2003). 
olarak laik modeller uygulanmakla birlikte teokratik modellere de rastlanmaktadır. ${ }^{37}$ Ana gövde olarak bu iki model içerisinden doğup, küçük çaplı farklılıklarla uygulanan alt modellerin varlığından da bahsetmek mümkündür. Modern devletlerde dini kurumların statüsü ve finansmanı, dini gruplar ile devlet arasındaki ilişki, din eğitimi ve dini hizmetler, cami, kilise, sinagog gibi ibadet yerlerinin toplum içerisindeki konumu vb. pek çok güncel soru doğal olarak karşımıza çıkmaktadır. ${ }^{38}$ Modern devletin din karşıtı kurmaya çalıştığı ana unsurlardan birisi de 'ulus devlet' modelidir. Ulus devlet anlayışı karmaşık halde yaşayan pek çok toplumu milli bir forma dönüştürmüştür. Böylece modern devlet ulus kimliğini dini kimliğin de önüne koyarak, ortak milli kültür etrafında vatandaşlık inşa etmeye çalışmıştır. ${ }^{39}$ Türkiye de ulus-devlet sürecini gerçekleştiren bir ülke olmuştur. Hukuki olarak Türk milleti kimliği anayasada tanımlanmış ve devlet bir millet kimliğine kavuşturulmuştur. Laik sistem benimsenmiş, din ve devlet işleri birbirinden ayrılmıştır. Bunun bir yansıması olarak İslam dininin siyasal, kültürel ve toplumsal konularda elinde bulundurduğu güç sınırlandırılmıştır. ${ }^{40}$

Devletin kuruluşundan itibaren Türkiye'de din konusu devamlı tartışma alanlarından birisi olmuştur. Dinin kamusal alanda yer alıp alamayacağı, dini kurumların açılıp açılamayacağı, dini sembollerin giyilip giyilemeyeceği, dini eğitimin verilip verilemeyeceği gibi hususlar modern Türkiye'de sürekli bir tartışma alanı olmuştur. Laiklik eksenli kurgulanan devlet sisteminde ibadetlerin nasıl yapılacağı, din hizmetlerinin nasıl karşılanacağı konuları ilk dönemlerde muamma bir alanı oluşturmuştur. Modern düşünce dinin bütünüyle kamusal alandan çekilmesini amaçladığı için bir devlet sisteminde dinin nasıl konumlanacağına dair tutarlı bir açıklama getirmemiştir. Oysaki Türk toplumunun sahip olduğu dini ve ahlaki temeller dinin devlet sisteminde bir yere oturtulmasını zaruri kılmaktadır. ${ }^{41} \mathrm{Bu}$ durum aynı zamanda dinin gayri resmî kurumlar aracılığıyla topluma verilmesinin de önünü açmıştır. Türkiye'de cemaatsel yapılanmaların Cumhuriyet döneminde artmış olmasının, dinin modern devlette konumlanma sorunuyla doğrudan ilgisi bulunmaktadır. Devletin sağlaması gereken din hizmetlerini geri plana attığı bir yapıda, tüzel kimliğe sahip olmayan ama aynı amacı taşıyan dini gruplar cemaatleşme yoluna gitmişlerdir.

37 Nilüfer Göle, Seküler ve Dinsel: Aşınan Sinırlar (İstanbul: Metis Yayınları, 2017), 15-19.

38 Ali Köse - Talip Küçükcan, AB Ülkelerinde Din-Devlet İlişkileri (İstanbul: İSAM Yayınları, 2008 ), 7.

39 Ernest Gellner, Uluslar ve Ulusçuluk, çev. Büşra Ersanlı \& Göksu Özdoğan (İstanbul: Hil Yayınları, 2008), 78-79.

40 Andrew Davison, Türkiye'de Sekülarizm ve Modernlik, çev. Tuncay Birkan (İstanbul: İletişim Yayınları, (2012), 219.

41 Celaleddin Çelik, “Türkiye'de Dini Hayatın Sosyo-Tarihsel Boyutları ve Dindarlığın Dönüşen Görünümleri", Bilimname Dergisi 1 (2018), 216. 


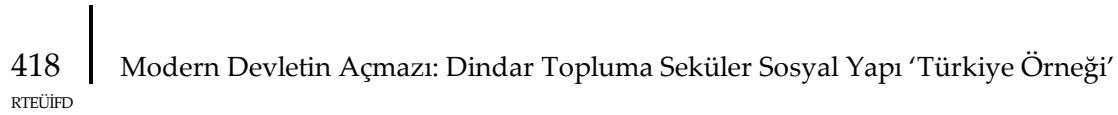

Modern Türkiye'nin dizaynıla dine biçilen rol kendi alanına çekilerek, devletin hukuki, siyasi, kültürel, ekonomik alanlarından tamamen uzaklaşmasıdır. Buna karşın büyük ölçüde Osmanlı bakiyesi olan toplumun sahip olduğu inanç ve manevi dinamikler ile asırlara sirayet eden toplumsal ve kültürel teamülleri ortadan kaldırmak kolay olmamıştır. ${ }^{42}$ Türkiye'de devletin seküler sistemi ile toplumun bilhassa muhafazakâr/dindar kesimi Cumhuriyetten beri mücadele içerisinde olmuştur. Bunun en önemli nedenini Türkiye' de İslami reform/modernizm dururken, batı modernizminin esas alınması oluşturmaktadır. ${ }^{43}$ Öyle ki Cumhuriyetin ilanıyla Osmanlı siyasi, hukuki, kültürel, sosyal ve dini yapısından önemli ölçüde kopuş meydana gelmiş ve batı tarzı yeni bir düzen tanzim edilmiştir. Türkiye'de gerek siyasal alandaki laiklik kavramı gerekse toplumsal alandaki sekülerlik kavramı dini kendi egemenlikleri altında tutma amacı gütmüştür. ${ }^{44}$ Bu noktada Türkiye' de yapının sekülerliği ile toplumun sekülerliğini tartışmak gerekmektedir.

\section{Türkiye'de Yapı Mı Seküler Yoksa Toplum Mu?}

Türkiye'de modernleşme deneyimi siyasal ve toplumsal açıdan karşıtlıklar üreten, sancılı bir süreç olmuştur. Türkiye'nin modernleşme adımları beraberinde Fransız tipi jakoben laikliği getirmiş, yeni sistemde kamusal alanda dine ve din merkezli değerlere yer verilmemiştir. Türk toplumunun tarihsel tecrübesi çok uzun zamandır dinle iç içe bir hayata dayanmaktadır. ${ }^{45}$ Din; sosyal, kültürel, hukuki ve siyasal sistemin ana aktörlerinden olmuştur. Böyle bir sürecin akabinde dinle çok ani ve hızlı bir ilişki değiştirme biçimine girmek evvela toplumsal travmalara neden olmuştur. Toplum geçmişten gelen tarihi, dini, kültürel birikime bir anda yabancılaştırılarak yeni bir hafıza ve tecrübe yaratım sürecinin içerisine sokulmuştur. Kurumlar seküler çerçevede yeniden şekillendirilmiş, dinin belirleyiciliği tamamen sonlandırılmıştır. Siyasal ve hukuki sistemin yasalarla teminat altına alındığı dini, sosyal ve kültürel süreçlerin yürürlüğe konulduğu Cumhuriyet döneminde, Anadolu kırsalına da seküler doktrinlerin ihraç edilmesi için Köy Enstitüleri gibi bazı kurumlar ihdas edilmiştir. ${ }^{46}$ Böylece topyekûn bir dönüşümün sağlanması amaçlanmıştır.

Cumhuriyetin ilk yıllarında baskıcı ve itaat ettirici mekanizmaların devreye sokulmasıyla dindar toplumun bütüncül olarak sisteme karşı çıkmasının önüne geçilebilmiştir. 1923-1950 yılları arası seküler inşa süreçleri süratle devam etmiştir. Türkiye'de toplumun din ve dini kurumlarla yeniden buluşması 1950'li yıllardan itibaren gerçekleşmiştir. İmam-Hatip Okullarının açılması, İlahiyat Fakültelerinin

42 Necdet Subaşı, Öteki Türkiye'de Din ve Modernleşme (İstanbul: Kopernik Yayınları, 2018), 162.

43 İsmail Kara, Din İle Modernleşme Arasında (İstanbul: Dergâh Yayınları, 2016), 190-192.

44 Mustafa Aydın, Moderniteye Dışardan Bakmak (İstanbul: Açlım Kitap, 2009), 110-111.

45 Şentürk vd., Türkiye'de Dindarlık, 44-45.

46 Bayram Kaçmazoğlu, Türk Sosyoloji Tarihi III (İstanbul: Doğu Kitabevi, 2018), 208. 
kurulması bu tarihlere denk gelmektedir. ${ }^{47} \mathrm{Bu}$ tarihler normalleşme süreci ile toplumun dini taleplerini yeniden kamusal alana taşıma isteklerinin olduğu döneme tekabül etmektedir. Yoğun bir sekülerleştirme programının uygulandığ ilk döneme rağmen toplumun dini kurum ve kuruluşlara bu denli rağbet etmesi dinselliğin halen daha baskın olduğu ancak yapının seküler olduğu için buna izin vermediğinin ilk işaretleri olarak değerlendirilebilir. Henüz küreselleşme, popüler kültür, tüketim gibi seküler eğilimlerden yana olan süreçlerin başlamadığı bir dönemde dinin bu derece revaçta olması dikkat çekicidir. Dinin toplumsal ve kamusal alandan uzaklaştırılmasıyla sanata ve kültüre dair her şey dinden bağımsız oluşturularak, birey ve toplum insan merkezciliğe doğru sürüklenmek istenmiştir. Bireyin, yaptığ1 her şeyi kendi başarısı ve üstün meziyetleri olarak görerek, doğaüstü varlığa ihtiyaç duymayacağı hissi verilmeye başlanmıştır. Bu durumun beraberinde dini ve kültürel yabancılaşma üretmesi, bunun üzerinden de yeni bir toplum tipolojisi yaratılmak istenmiştir. ${ }^{48}$ Seküler sistem sadece siyasal ve hukuki alanı kuşatmamış aynı zamanda diğer alanları da belli bir kalıba sokmuştur. Türk toplumunda ekonomi, kültür, sanat ve eğitim de seküler kurallarla donatılmıştır.

Bireylerin çalışma hayatındaki şartlarından ticaret hayatındaki şartlara, ibadet hayatındaki koşullardan tüketim hayatındaki koşullara, hukuk ve eğitim sisteminden kültürel ve sanatsal ürünlere kadar birçok alan seküler inşa sürecine tabi tutulmuş, bu durum doğrudan topluma yansımıştır. Örneğin çalışan bir bireyin (memur, işçi vb.) gündelik namaz veya Cuma namazını kılma koşullarının sağlanıp sağlanmaması bireyin değil sosyal yapının bir problemidir. Öyle ki çalışma hayatının koşulları buna izin vermeyebilir. Başka bir örnekte ticaret yapan bir müteşebbisin parasal olanaklara erişiminin bankalarla sınırlanması dolayısıyla faiz ile içli dışlı olması bireyin değil yapının bir problemidir. Çünkü yapı bireye alternatif bir sistem önermek yerine bireyi seküler bir sistemin kucağına itmektedir. Kent hayatının devamlı geliştirilmesi, endüstri ve teknolojinin yeni imkanlar üretmesi, modern tıbbın ilerlemesi bireyi daha fazla seküler tercihlere yöneltmektedir. ${ }^{49}$ Benzer şekilde aktüel bir örnek olarak tüketim çılgınlığı ve bilinçsiz harcama sistemin teşviki ile gerçekleştirilen eylemlerdir. Reklam ve televizyon aracılığıyla tanıtımı yapılan birçok öğe bireye ve topluma adeta ideal olarak takdim edilmekte ve bu ürünlere sahip olmama toplum dışına itilme riskiyle özdeşleştirilmektedir. Birey, modern toplumun bir parçası olmak ve denklemin içinde kalmak adına tercihini tüketmekten yana kullanmaktadır. ${ }^{50}$

47 Yasin Aktay, Türk Dininin Sosyolojik Imkânı (İstanbul: İletişim Yayınları, 2006), 191.

48 İzzet Er, Din Sosyolojisi (Ankara: Akçă̆ Yayınları, 2008), 291-292.

49 Volkan Ertit, Endişeli Muhafazakârlar Çă̆̆ (Ankara: Orient Yayınları, 2018), 24-36.

50 Şahinde Yavuz, "Türk Toplumunun Tüketim Toplumuna Dönüşümünde Reklamcllığın Rolü", Gazi Üniversitesi İletişim Kuram ve Araştırma Dergisi 36 (Bahar 2013), 235. 


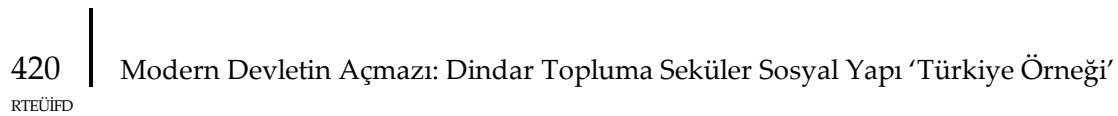

Modern Türkiye'de Arap alfabesinin lağvedilmesiyle kendi kültürel, dini birikimlerine ve entelektüel kaynaklarına yabancılaşan bir toplum ortaya çıkmıştır. Aynı zamanda yeni ihdas edilen Latin alfabesiyle batı menşeli bir kültürel üretim sürecine girilmiştir. Yüksek kültürün ideal kültür olarak takdim edildiği bu süreçte sosyal yapıdaki kurumlar da yüksek kültür çerçevesinde şekillendirilmiştir. Buna karşın toplumun önemli bir kesiminin dahil olduğu halk (folk) kültürü sistematik şekilde geri plana atılmıştır. Ancak halk kültürü daha çok milli, dini ve yerel unsurlara dayanırken, yüksek kültür modern ve seküler batı sisteminden beslenmektedir. Sosyal yapının modernitenin bir gereği olarak yüksek kültürle bezenmesi, halk kültürünün şekillendirdiği dindar kesimi kamusal alanda yüksek kültürle yüzleşmeye mecbur bırakmaktadır. Bu durum kültürel bağlamda dindarlarda halk kültürünün yerini batı eksenli yüksek kültür pratiklerinin almasına neden olmaktadır.

Aynı bağlamda hukuk sisteminin medeni hukuk çerçevesinde oluşturulması dindar toplumda da modern hukuka göre hareket etme mecburiyeti yaratmaktadır. Bunun bir getirisi olarak aile, miras, ceza, boşanma hukuku gibi konularda bireylerin sistemin bir dayatması olarak modern hukuka göre tercih yaptıkları görülmektedir. Hukuk sisteminin alternatif bir yapıya sahip olması kişisel tercihleri farklı hukuki uygulamalara yöneltebilir. Toplum seküler sistemin içerisine girdikçe kendi sistemi ile yabancılaşma süreci yaşama riskiyle karşılaşmaktadır. Türkiye'de sanatsal alanın dizaynı da benzer bir sorunla karşı karşıya kalmıştır. Türk toplumunda sanat batı dünyasıyla özdeşleştirilmektedir. Moderniteyle birlikte batının örnek alınarak sanatsal gelişme sağlanabileceği doktrinel bir şekilde topluma anlatılmaktadır. ${ }^{51}$ Eğitim sistemi içerisinde resim, müzik, heykelcilik gibi alanlarda batı sanatının tatbik edilmesi aynı şekilde yapının yarattığı bir sekülerliktir. Sinema, opera, bale gibi batı merkezli sanatsal aktivitelerin topluma ideal olarak takdim edilmesi ve kitlelerin bu alanlara yöneltilmesi yine toplumun değil yapının sekülerliğine işaret etmektedir. Aynı yapı topluma ebru, hat, tezhip gibi İslami sanatları ideal olarak sunabilir ve bu alanlara bireyleri kanalize edebilir.

Sosyal yapının sekülerliği çerçevesinde bilhassa eğitim sistemini de ele almak gerekmektedir. Siyasal alandaki devlet erkinde laik bir bakış açısıyla oluşturulan eğitim sistemi ideolojik bir angajmana tabi tutulmuş ve modern devletin aşama aşama topluma sirayet ettirilmesinde manivela olarak kullanılmıştır. Zihinsel bir dönüşüme aracılık etmesi için tasarlanan eğitim sistemi bilimin mutlaklaştırılması, metafizik alana hitap eden din kurumuna fazla itibar edilmemesi, pozitivist ve materyalist bir yaklaşımın benimsenmesi, batı öykünmeciliği gibi hedeflerin aracısı kılınmıştır. ${ }^{52}$ Böylece bireyin eğitim ile yaşadığı dönüşümde toplumsalın içinde kendini var eden

51 Ali Artun, Modernizm Kavramı ve Türkiye'de Modernist Sanatın Doğuşu (İstanbul: İletişim Yayınları, 2021).

52 Orhan Türkdoğan, Türk Toplumunun Kültürel Dinamikleri (Konya: Çizgi Kitabevi, 2015), 442-444. 
seküler sosyal yapının belirgin bir rolü olmuştur. Türkiye'de birçok alanda Cumhuriyetin kuruluşundan beri seküler sosyal yapı ile karşılaşılmaktadır. Özellikle kültür, iş ve eğitim alanlarında ön plana çıkan seküler sosyal yapı, toplumun seküler eğilimlerinde belirleyici bir rol üstlenmektedir. Türk toplumunun geniş bir kesimi dindar popülasyonu temsil etmekle birlikte içinde bulundukları sosyal yapı uzunca bir süredir seküler unsurlarla oluşturulmuştur. Bu durum dindar kesimin dinle ilişkisinde birtakım aşınmalara sebebiyet vermiştir. Bu çerçevede dindarlığı bireysel, toplumsal ve kurumsal olmak üzere üç kategoride ele alarak, toplumun bireysel düzlemde din ile ilişkisini zayıflattığı ancak toplumsal ve kurumsal düzlemde güçlü şekilde ilişkisini sürdürdüğü söylenebilir.

\section{SONUÇ}

Devlet, din ve sekülerleşme ilişkisini Türkiye örneği üzerinden tartışmaya çalıştığımız makalede, modern devlette seküler sosyal yapı aracılığıyla dinin etki alanının nasıl kısıtlandığı ve bu durumun toplumdaki dindar kesimi nasıl etkilediği üzerinde durulmuştur. Ayrıca Türkiye' de din kurumunun toplumsal gücüne rağmen sosyal yapının devlet eliyle nasıl sekülerleştirildiği ortaya konulmuştur. Bu bağlamda modernizmin 20. yüzyıl Türkiye toplumunu okuma noktasında yeterince başarılı olamadığını anlamaktayız. Dinin yerine ikame etmeye çalıştığı sekülerliğin dini alanı daraltmasına rağmen dindar toplumu yeterince dönüştüremediği görülmüştür. Dinin içinde barındırdığı ilahi unsurların yerini, seküler sistemde dolduracak aşkın bir varlık bulunamamıştır. Toplumu oluşturan birey, sadece doğaya değil doğaüstülere de ihtiyaç duymaktadır. Bu iç hissiyat herhangi bir devrim yoluyla değiştirilemez. Modernitenin algılayamadığı en önemli nokta da belki de burasıdır. İnsanların dini pratikleri ve ritüelleri zaman zaman inişli çıkışlı bir grafik ortaya koysa da dinin zihinlerdeki varlığı her zaman kalıcılığını muhafaza etmiştir. Dolayısıyla dinin bireysel gücü azalsa da toplumsal ve kurumsal gücü devam etmektedir.

Türkiye'de dinin kamusal alanda uzun yıllar muğlak bir yerde durduğu görülmüştür. Toplumun dini ve kültürel arka planıla yeni seküler sistemin uyuşmadığı anlaşılmıştır. Ancak sosyal yapının seküler kurulumu ile toplumun sekülerliği aynı potada eritilmek istenmiştir. Halbuki seküler olan sosyal yapının kendisi iken toplum bu sekülerliğe zaruri olarak katlanmaktadır. Sistemin dayatması ile toplumun tercihi arasındaki derin paradoksta modern devletin yasal yaptırımlarının etkili olduğu düşünülmektedir. Toplum, seküler sosyal yapının dayatmalarına maruz kalırken, gündelik yaşam pratiklerini ve tercihlerini dönüştürmek mecburiyetinde bırakılmaktadır. Bu keyfi bir dönüşüm olmayıp, yapının yarattığı ortamın bireye ve topluma yansıma biçimidir. Bundan ötürü uzun yıllar devlet ve toplum arasında bir aidiyet ve sahiplenme problemi yaşanmıştır. 


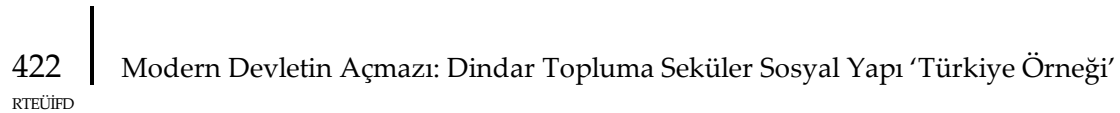

Dinin bireysel olarak seküler unsurlardan etkilendiği ve gündelik pratikleri belirlemede referans gücünü belli oranda kaybettiği düşünülürken, toplumsal ve kurumsal yönüyle bireyin ve toplumun hafızasında canlı şekilde durduğu anlaşılmaktadır. Birey, rutin yaşantısı içerisinde sosyal yapının ona sunduğu şartlar doğrultusunda bazen dinin taleplerini görmezden gelirken, zihni ve psikolojik dünyasında aşkın varlıkla güçlü bir bağ kurmaktadır. Bu durum zaruri olarak dinin soyut alanda mevzilenmesine sebebiyet vermektedir. Modern akıl seküler devleti kurguladığı gibi seküler insanı da kolaylıkla kurgulayabileceğini düşünmüş ancak dinin ontolojik yönünün birey ile kurduğu ilişkinin, devlet ile kurulan ilişkiden çok daha farklı dinamiklere dayandığını idrak edememiştir.

Modernite yapı ile toplumu dönüştürmek isterken, yapıyı dönüştürdüğü gibi toplumu da tamamen dönüştürebileceğini varsaymıştır. Bu durum modern devlette paradoksal bir sosyal yapı ve toplum ilişkisinin türemesine neden olmuş, yapının sekülerliği ile toplumun sekülerliği özdeşleştirilmiştir. Günümüzde sekülerleşmeden bahsedilirken doğal akışı içinde oluşan bir toplumsal sekülerleşmeden değil, yapının hazırladığı bir toplumsal sekülerleşmeden bahsetmek daha doğru olacaktır. 


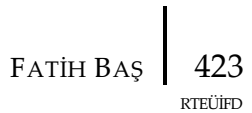

\section{KAYNAKÇA}

Abuzar, Celil. “Din-Toplum Etkileşimi ve Eğitim”. Harran Ĕ̆itim Dergisi 2/2 (2017), 50- 58.

Akkaya, Şükrü. “Hümanizm' in Çıkışı ve Yayılışı”. Ankara Üniversitesi Dil ve TarihCoğrafya Fakültesi Dergisi 5/2 (1947), 199-222.

Aktay, Yasin. Türk Dininin Sosyolojik Imkânı. İstanbul: İletişim Yayınları, 2006.

Akyüz, Niyazi - Çapçıŏlu, İhsan. Din Sosyolojisi. Ankara: Grafiker Yayınları, 2012.

Artun, Ali. Modernizm Kavramı ve Türkiye'de Modernist Sanatın Doğuşu. İstanbul: İletişim Yayınları, 2021.

Aydın, Mustafa. Moderniteye Dışardan Bakmak. İstanbul: Açılım Kitap, 2009.

Aydın, Mustafa. Güncel Kültürde Temel Kavramlar. İstanbul: Açılım Kitap, 2011.

Berkes, Niyazi. Türkiye'de Çağdaşlaşma. İstanbul: Doğu-Batı Yayınları, 1988.

Casanova, Jose. "The Secular and Secularisms". Journal of Social Research 76/4 (2009), 1049-1066.

Coşkun, Seyit. "Sosyal Bilimlerde Metodoloji Problemi”. Dört Öge Dergisi 13 (Haziran 2018), 63.

Çelik, Celaleddin. “Türkiye'de Dini Hayatın Sosyo-Tarihsel Boyutları ve Dindarlığın Dönüşen Görünümleri". Bilimname Dergisi 1 (2018), 215-249.

Davison, Andrew. Türkiye'de Sekülarizm ve Modernlik. çev. Tuncay Birkan. İstanbul: İletişim Yayınları, 2012.

Engels, Frederic. Ailenin, Özel Mülkiyetin ve Devletin Kökeni. Ankara: Alter Yayıncılık 2013.

Er, İzzet. Din Sosyolojisi. Ankara: Akçağ Yayınları, 2008

Ertit, Volkan. Sekülerleşme Teorisi. Ankara: Liberte Yayınları, 2019.

Ertit, Volkan. Endişeli Muhafazakârlar Çă̆̆ı. Ankara: Orient Yayınları, 2018.

Esmer, Yılmaz. Türkiye Değer Atlası. İstanbul: Bahçeşehir Üniversitesi Yayınları, 2012.

Haldun, İbn. Devlet. çev. Osman Arpaçukuru. İstanbul: İlke Yayıncılık, 2003.

Harman, Ömer Faruk. "Din ve Vicdan Hürriyeti”. Türkiye Diyanet Vakfı İslam Ansiklopedisi. 9/340. İstanbul: Türkiye Diyanet Vakfı Yayınları, 1994.

Gellner, Ernest. Uluslar ve Ulusçuluk. çev. Büşra Ersanlı \& Göksu Özdoğan. İstanbul: Hil Yayınları, 2008. 


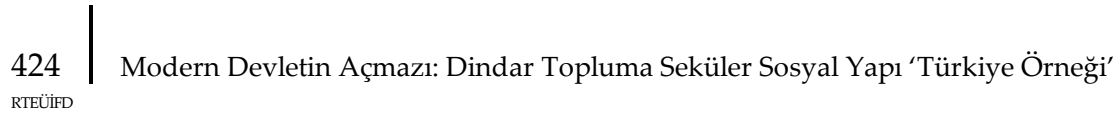

Giddens, Anthony. Modernliğin Sonuçları. çev. Ersin Kuşdil. İstanbul: Ayrıntı Yayınları, 2016.

Göle, Nilüfer. Modern Mahrem. İstanbul: Metis Yayınları, 2011.

Göle, Nilüfer. Seküler ve Dinsel: Aşınan Sınırlar. İstanbul: Metis Yayınları, 2017.

Günay, Ünver. Din Sosyolojisi. İstanbul: İnsan Yayınları, 2012.

Kara, İsmail. Din İle Modernleşme Arasında. İstanbul: Dergâh Yayınları, 2016.

Karadaş, Cağfer. “Selçukluların Din Politikası”. Necmeddin Erbakan Üniversitesi İlahiyat Fakültesi İstem Dergisi 1/2 (2003), 95-108.

Kirman, Mehmet Ali - Çapcıoğlu, İhsan. Sekülerleşme: Klasik ve Çă̆daş Yaklaşımlar Ankara: Otto Yayınları, 2015.

Kaçmazoğlu, Bayram. Türk Sosyoloji Tarihi III. İstanbul: Doğu Kitabevi, 2018.

Köprülü, Mehmet Fuad. Anadolu'da İslamiyet. haz. Hasan Aksakal. İstanbul: Alfa Yayınları, 2017.

Köse Ali. Kutsalın Dönüşü. İstanbul: Timaş Yayınları, 2014.

Köse, Ali - Küçükcan, Talip. Avrupa Birliği Ülkelerinde Din-Devlet İlişkisi. İstanbul: İsam Yayınları, 2008.

Küçükcan, Talip. "Modernleşme ve Sekülerleşme Kuramları Bağlamında Din, Toplumsal Değişme ve İslam Dünyası". İslam Araştırmaları Dergisi 13, (2005), 109-128.

Landau, Mark. Atatürk ve Türkiye'nin Modernleşmesi. çev. Meral Alakuş. İstanbul: Sarmal Yayınevi, 1999.

Levi-Strauss, Claude. "Sosyal Yapı”. çev. Erdoğan Güçbilmez. Ankara Üniversitesi Siyasal Bilgiler Fakültesi Dergisi 20/2 (1965), 681-713.

Luckman, Thomas. Görünmeyen Din: Modern Toplumda Din Sorunu. çev. Ali Coşkun vd. İstanbul: Rağbet Yayınları, 2016.

Martin, David. A General Theory of Secularization. Oxford: Blackwell Publishing, 1978.

Mardin, Şerif. Türkiye, İslam ve Sekülarizm. İstanbul: İletişim Yayınları, 2011.

Mardin, Şerif. Türkiye'de Din ve Siyaset. İstanbul: İletişim Yayınları, 2012.

Özay, Mehmet. Sekülerleşme ve Din. İstanbul: İbn Haldun Üniversitesi Yayınları, 2020.

Subaşı, Necdet. Öteki Türkiye'de Din ve Modernleşme. İstanbul: Kopernik Yayınları, 2018.

Stark, Rodney. "Secularization”. Journal of Sociology of Religion 60/3 (1994), 237-241. 
Şentürk, Recep vd. Türkiye'de Dindarlık. İstanbul: İletişim Yayınları, 2012.

Taylor, Charles. Seküler Çă̆. İstanbul: Türkiye İş Bankası Yayınları, 2014.

Tekin, Mustafa. Kutsal Sekülarizm. İstanbul: Açılım Kitap, 2011.

Türkdoğan, Orhan. Türk Toplumunun Kültürel Dinamikleri. Konya: Çizgi Kitabevi, 2015.

Weber, Max. Bürokrasi ve Otorite. çev. Bahadır Akın. Ankara: Adres Yayınları, 2017.

Wilson, Bryan. Seküler Toplumlarda Din. çev. Ömer Faruk Darende. Ankara: Pegem Yayınları, 2017.

Yavuz, Şahinde. “Türk Toplumunun Tüketim Toplumuna Dönüşümünde Reklamcılığın Rolü”. Gazi Üniversitesi İletişim Kuram ve Araştırma Dergisi 36 (Bahar 2013), 219-240.

Yılmaz, Hakan. Türkiye'de Muhafazakarlık, Aile, Din ve Batı, Yayımlanmamış Araştırma Raporu. Ocak 2006.

Zürcher, Erik Jan. Modernleşen Türkiye'nin Tarihi. çev. Yasemin Saner. İstanbul: İletişim Yayınları, 2018. 